\title{
MUNKAHELYEK EGÉSZSÉGTUDATOSSÁGÁNAK VIZSGÁLATA HAJDÚ-BIHAR MEGYÉBEN
}

\author{
Szerzők: \\ Balatoni Ildikó (PhD.) \\ Debreceni Egyetem (Magyarország) \\ Kosztin Nikolett (Med.) \\ Debreceni Egyetem (Magyarország) \\ Első szerző e-mail címe: \\ balatoni@med.unideb.hu
}

Lektorok:

Balatoni I. és Kosztin N. (2020). Munkahelyek egészségtudatosságának vizsgálata Hajdú-Bihar megyében. Különleges Bánásmód, 6. (2). 7-18. DOI 10.18458/KB.2020.2.7

\begin{abstract}
Absztrakt
Kutatásunk során azt vizsgáltuk, vajon a munkáltatók szempontjából mennyire fontos a munkavállalók mentális és testi egészségének fenntartása. Olyan Hajdú-Bihar megyei vállalkozásokat kérdeztünk meg, akik nettó árbevételük alapján a TOP 100-as listán szerepelnek. Nemzetgazdasági ágak szerint leginkább képviselt a feldolgozóipar, a szolgáltatás, a kereskedelem, a mezőgazdaság és az építőipar. Vizsgáltuk, hogy az adott cég biztosít-e munkavállalói számára egészségtudatosságot célzó juttatást. A válaszadók között elvétve szerepeltek, akik a kötelező orvosi vizsgálatokon felül lehetőséget nyújtanak különböző szakorvosi ellátásokra, kedvezményes edzőtermi- vagy úszóbérletre, ugyanakkor többen szerveznek egészség- és sportnapokat. Megállapítható, hogy szükség van munkahelyi egészségfejlesztésre, ehhez azonban elengedhetetlen a munkaadók szemléletének változása.
\end{abstract}

Kulcsszavak: munkahelyi egészségfejlesztés, egészség, munkavállalók, munkáltatók

Diszciplina: társadalomtudomány, gazdaságtudomány, egészségtudomány

\begin{abstract}
HEALTH AWARENESS IN WORKPLACES OF HAJDÚ-BIHAR COUNTY

In our research, we examined the importance of maintaining the mental and physical health of employees from an employer perspective. To this end companies in Hajdú-Bihar county who are listed in the TOP 100 based on their net revenue were interviewed. The most represented economic sectors in this relation were processing, services, trade, agriculture, and construction. We examined whether companies provided any benefits to their employees concerning health awareness. Among respondents those who
\end{abstract}


offered various services of medical specialists and/or discounted gym or swim passes in addition to compulsory medical examinations were hard to find, however, more employers organize health and sports days. In conclusion, while workplace health promotion is necessary it requires a change in employers'attitudes.

Keywords: corporate health promotion, health, employees, employers

Disciplines: social science, economics, health science

Napjainkban a fizikai inaktivitás és az egészségtelen táplálkozás olyan méreteket öltött, hogy felelôs a globális halálozások 60\%-áért (Waxman, 2004). Tekintettel arra, hogy felnőtt életszakasz jelentős részét, közel egyharmadát a munkahelyen töltik el az emberek és hogy a munkavállalók körében egyre nagyobb azoknak az aránya, aki üló foglalkozást végeznek - ezzel jelentősen hozzájárulva ahhoz, hogy a társadalom felnőtt tagjainak fizikai aktivitása csökken - a munkahelyi egészségfejlesztésnek jelentős szerepe lehet ezen helyzet javításában. A korábban bevezetett központi adminisztratív intézkedések, mint például a dohányzás és/vagy alkohol fogyasztás megtiltása a munkahelyeken, bizonyos országokban pozitív eredményre vezetett (Bordado Sköld et al., 2019).

$\mathrm{Az}$ elmúlt néhány évtizedben a túlsúly és az elhízás prevalenciája gyorsan terjedt, oly mértékben, hogy a fejlett világban járványnak tekinthető, ugyanakkor a fejlődő világban is tért hódít. Epidemiológia vizsgálatok rámutattak, hogy azon munkavállalók körében, akik hosszabb idejű, vagy múszakos munkarendben dolgoznak, ezek a problémák lényegesen gyakoribbak (Mehta et al, 2013; Shulte et al., 2007).

A munkahely egy olyan helyszínnek tekinthető, ahol a fizikai inaktivitás és az elhízás elleni programokat viszonylag könnyú megvalósítani. A munkahely ugyanis egy olyan kontrollált környezet, ahol a felnôtt populáció jelentős része munkahelyi programok keretében könnyen elérhető (Engbers et al., 2005; Katz et al., 2005). Ugyanakkor a munkáltatók számára az a lehetőség, hogy olyan munkahelyi programok bevezetésével, amelyek növelik a fizikai aktivitást a termelékenységet növeljék, miközben az egészségügyi kiadásokat csökkentik, igen vonzó (Dishman et al., 1998).

Kutatásunk során arra voltunk kíváncsiak, hogy a Hajdú-Bihar megyei vállalatok milyen egészségfejlesztési programokat indítottak el munkavállalóik egészségének megőrzése érdekében.

\section{Irodalmi áttekintés}

Az USA-ban végzett vizsgálat szerint 2014-ben azon munkáltatók 74\%-a, akik egészségbiztosítást kínáltak munkavállalóiknak, legalább egy alkalommal „wellness” programot is szervezett (NavratilStrawn, 2016). Az ehhez kapcsolódó meta-analízis megállapította, hogy minden egyes munkahelyi egészségfejlesztésre elköltött dollár 3,27 dollár megtakarítást eredményezett az egészségügyi kiadásokban (Baicker et al., 2010).

Számos elemzés mutatott rá arra, hogy a fizikai aktivitás hiánya potenciális kockázati tényező a munkahelyi távollét és a munkahelyi teljesítmény szempontjából (Sjogaard et al., 2016). Minél nagyobb a munkahelyi feladatok által okozott feszültség, annál kevesebb a szabadidőben végzett fizikai aktivitás. A szerzők, 15 Dániában lefolytatott randomizált kontrollált vizsgálatok alapján leírták azt is, hogy a munkahelyeken bevezetett, a fizikai 
aktivitás növelésére irányuló programok szignifikánsan csökkentették a nyaki fájdalmat az irodai és számítógépes munkát végzők körében, valamint a kardiovasculáris és kardiometabolikus betegségek előfordulását is. Kleimann és munkatársai (2014) rámutattak arra, hogy az Egyesült Államokban az elhízással kapcsolatos egészségügyi kiadások az 1995-ben elköltött 52 Mrd dollárról 2008-ra megközelítőleg 147 Mrd dollárra emelkedtek. Ez egyúttal azt is jelenti, hogy az elhízással kapcsolatos kiadások a teljes egészségügyi kiadások 5\%-ról, azok közel 10\%-ára emelkedtek. Két tanulmány (Wolf és Colditz, 1998; Thompson et al., 1998) azt is megállapította, hogy ezekkel párhuzamosan a munkáltatók elhízáshoz köthető táppénzzel és munkaképtelenséggel kapcsolatos költsége 2,4 Mrd és 800 millió dollár volt 1994-ben, ami együtt járt 39,2 millió kiesett munkanappal. Szerzők több, mint 70000 munkavállalót érintő felmérése alapján arra a következtetésre jutottak, hogy a magasabb testtömeg index szignifikánsan nagyobb munkáltatói egészséggel kapcsolatos kiadásokkal, valamint a munkavállalók saját bevallásán alapuló csökkent termelékenységgel jár.

Groeneveld és munkatársai (2010) 31 randomizált kontrollált vizsgálatot elemezve kimutatták, hogy a munkahelyi életmódváltásra irányuló programok jelentős csökkenést eredményeztek a testzsír \%-os arányában, ezzel párhuzamosan a kardiovaszkuláris betegségek rizikócsoportjába tartozó munkavállalók körében szignifikáns testtömeg csökkenést értek el. Hasonló következtetésre jutottak Proper és Oostrom (2019), akik ezen túlmenően arra is rámutattak, hogy a munkahelyi TRX (Totalbody Resistance Exercise) edzés hozzájárul a mozgásszervi megbetegedések megelőzéséhez.

A munkahelyi egészségfejlesztés kérdéskörét kutatók vizsgálták a táplálkozás szempontjából is (Conn et al., 2009; Engbers et al., 2005). Megállapították, hogy a munkahelyi fizikai aktivitás és az ott bevitt energia mennyiség nincs egyensúlyban egymással, ami növeli az elhízottak arányát a munkavallók körében. A depresszió és a szorongás a leggyakoribb mentális betegségek (Martin et al., 2009), melyeknek a prevalenciája folyamatosan növekszik. Mind Európában, mind az Egyesült Államokban a munkavállalók egyharmada állítja azt, hogy a munkahelyi stressz negatívan befolyásolja a teljesítményét. Számos kutatás mutatott rá arra (Sanderson és Andrews, 2006; McDaid et al., 2005), hogy a munkahelyeken megvalósított mentális támogató programok, melyek azt a célt szolgálják, hogy csökkentsék a depressziót és szorongást, alkalmasak ennek kezelésére, és mint ilyenek, pozitívan befolyásolják a mentális problémák miatti csökkent munkahelyi teljesítményt és távollétet. A munkahely olyan környezet, amely pszichológiai stresszt jelent, hiszen a munkahelyi elvárások és a folyamatos teljesítménykényszer jelen vannak (Chu et al., 2014). A vizsgálatok rámutattak arra, hogy a fizikai aktivitás javítja a mentális jóllétet is. Egyes kutatók szerint ennek hátterében a felszabaduló endorfinok állnak, amelyek mind perifériás, mind központi idegrendszeri hatásuk révén hozzájárulnak a jobb kedélyállapothoz (Peluso and Andrade, 2005). Mások a szimpatikus aktivitás fokozódását kísérô monoamin neurotranszmitterek ilyen jellegú hatásait is fontosnak tartják (Joung, 2007). Ugyanakkor Chu és munkatársai (2014) felhívták a figyelmet arra is, hogy ahhoz, hogy ezek a programok sikeresek lehessenek, egyénre szabottaknak kell lenniük, azaz, figyelembe kell vegyék a munkavállaló életkorát, nemét és társadalmi-gazdasági helyzetét.

Több, mint 450 tudományos kutatás alapján összefoglalóan megállapításra került (Joyce et al., 2016), hogy a kognitív viselkedésterápia alapú stressz kezelés jelentősen javítja a depressziót és a szorongást, ugyanakkor a traumát követő elbeszélgetések rutinszerú használata semmilyen javulást nem okoz a munkavállalók esetében. Mindezek arra utalnak, hogy a munkahelyeken a leggyakoribb mentális betegségek kezelésének és az azokból tör- 
ténő felépülésnek is megvannak a sajátos kezelési módjai (Carolan et al., 2017).

A Health, Productivity, and Performance Study Committee (HERO) 2015 évi jelentése - 519 amerikai egyesült államokbeli vállalatvezetô körében végzett felmérés alapján - megfogalmazta, hogy a munkahelyi vezetők többsége felismeri az egészség fontos szerepét a munkahelyi teljesítmény és hatékonyság szempontjából, de nem sorolják azt a legmeghatározóbb tényezők közé. Ugyanakkor rámutattak arra is, hogy minden olyan vezetőre, aki az egészséget fontos vállalati stratégiának tekinti, jut egy olyan is, aki az egészség védelmét szükséges költségnek véli. Bár a felsôvezetők általában elkötelezettek a munkavállalóik egészségének javitása iránt, a középvezetők körében ez az elkötelezettség kevésbé figyelhető meg.

Az előbbivel közel egyidőben megvalósított „The Willis Health and Productivity Survey" (2014) több mint 900 amerikai egyesült államokbeli vállalatvezetôt kérdezett meg a munkahelyi egészségmegőrző programokkal kapcsolatban. A kutatás megállapította, hogy egyre több szervezet próbálja egészségügyi kiadásait és kockázatait munkahelyi egészség és wellness programokkal csökkenteni, valamint hogy munkavállalóik egészségére nemcsak mint egészségügyi kiadást csökkentő tényezőre, hanem mint gazdasági értékre is tekintenek. Ugyanakkor - meglepó módon - a megkérdezett gazdasági szereplók igen kis hányada folytat arra irányuló adatgyújtést, hogy az ilyen programjaik ténylegesen milyen mértékben javítják a termelékenységet. A válaszoló gazdasági társaságok 68\%-a működtet valamilyen „wellness” programot. Ezeknek 78\%-a egyfajta motiváló tényezőt is alkalmaz, hogy a munkavállalók részt is vegyenek a programokon. Bár a munkáltatók 93\%-a meg van győződve arról, hogy az egészségesebb munkavállalók jobban teljesítenek, kevesebb, mint 20\%-uk végez ténylegesen ilyen irányú adatgyüjtést.

Egy vállalat esetében szükséges, hogy az egészségfejlesztés stratégiai irányai egyértelműek legye- nek. Kutatók rávilágítottak, hogy míg a menedzsment tagjainak körében elsősorban az a szemlélet uralkodik, hogy hogyan lehet a munkavállalók produktivitását fokozni, addig a foglalkozásegészségügy a betegségekkel és egészségügyi problémákkal kapcsolatos termelékenység csökkenés megelőzésére fókuszál (Koopmans et al., 2011).

Kutatók megállapították, hogy az egészségügyi állapot a munkahelyi termelékenységgel szoros összefüggést mutat (Schultz et al., 2009) és hogy a munkaadókat terhelő munkavállalói termelékenység csökkenésből származó bevétel kiesés jelentôs része abból származik, hogy a munkavállaló betegen is megy dolgozni, mert fél, hogy elveszti az állását. Ennek következtében az elmúlt évtizedekben a vállalatok kezdik elfogadni, hogy a legnagyobb vagyonuk az emberi tőke.

Az Európa 2020 Stratégia egyik legfontosabb célkitűzése a foglalkoztatás javítása. A fenntartható foglalkoztatás érdekében a European Network for Workplace Health Promotion (ENWHP) - melynek 28 ország tagja - célul túzte ki a munkahelyi egészség megfelelő gyakorlatának előmozdítását (Knoche et al., 2012). Tanulmányukban rávilágítottak arra, hogy minden európai vállalatnak szembe kell néznie, hogy munkavállalói idősödnek és ezzel együtt számos krónikus betegségben szenvednek. Munkaképességük megtartása ugyanakkor a vállalati siker záloga lehet. Az ENWHP céljai eléréséhez a következő eszközrendszerek együttes alkalmazását látja szükségesnek: a munkaszervezés javítását (rugalmas munkaidő, távmunka, egész életen át tartó tanulás lehetőségei), a munkakörnyezet javitását (ide értve az egészséges ételeket a menzán), a munkavállalók ösztönzését az egészségfejlesztési programokban való részvételre, valamint az egyéni kompetenciák fejlesztésének, személyi fejlődésnek az ösztönzése (mint például stresszkezelő, vagy dohányzásról történő leszokást segítő tanfolyamokon való részvétel) (FACTS, 2010).

A munka törvénykönyvéről szóló 2012. évi I. törvény kimondja, hogy a munkáltató biztosítja az 
egészséget nem veszélyeztetô és biztonságos munkavégzés követelményeit, valamint a munkába lépést megelőzően és a munkaviszony fennállása alatt rendszeres időközönként köteles ingyenesen biztosítani a munkavállaló munkaköri alkalmassági vizsgálatát. Az egészséges munkahely ugyanakkor túlmutat a munkavédelemi intézkedéseken, ide tartozik a sportolás, az egészséges ételek fogyasztása lehetőségének biztosítása és az egészség támogatása minden téren.

\section{Anyag és módszer}

Felmérésünket 2019 tavaszán végeztük. A megkérdezett vállalatok listáját a Hajdú-Bihari Napló 2018. évi "Top 100" címú kiadványában található, 2017-ben Hajdú-Bihar megye 100 legnagyobb nettó árbevételû vállakozásának felsorolása képezte. A megkeresettek közül 70 cég vállalta, hogy válaszol a kérdéseinkre. A kiadványban közzétett pénzügyi és munkavállalói létszámra vonatkozó adatokon túl, részben személyes, részben telefonos interjún alapuló kérdőíves vizsgálatunkban arra voltunk kíváncsiak, hogy milyen egészségmegőrzési lehetőségeket kínálnak munkavállalóiknak az egyes cégek.
A kérdôívek feldolgozására EvaSys programmal került sor.

2019 I. negyedévében Hajdú-Bihar megyében a 15-74 éves népesség 61,6\%-a, 246 ezer fő volt gazdaságilag aktív. A foglalkoztatási ráta 58,6\%, a munkanélküliségi ráta 4,7\% volt. Hajdú-Bihar megyei székhellyel 107 ezer gazdasági szervezetet tartottak nyilván. A vállalkozások 18\%-át társas gazdálkodási formában, 82\%-át önálló vállalko-zóként regisztrálták. A társas vállalkozások 91\%-a legfeljebb 9 fôt foglalkoztatott, a 249 fó feletti foglalkoztatóból 34 volt a megyében. Főtevékenységük alapján a társas vállalkozások a kereskedelem (24\%), a tudományos és műszaki tevékenység (15\%), az építőipar (11\%) és az ipar (9,5\%) területén, az önálló vállalkozók a mezőgazdaság (53\%) és az ingatlanügyletek $(9,9 \%)$ nemzetgazdasági ágakban fordultak elő leggyakrabban. A 4 főnél többet foglalkoztató ipari vállalkozások Hajdú-Bihar megyei telephelyein 215 milliárd forint termelési értéket állítottak elő, a 49 főnél többet foglalkoztató, megyei székhelyú ipari vállalkozások termelési értéke 189 milliárd forintot tett ki (KSH, 2019). A vizsgálatban résztvevő vállalatok nettó árbevételét vizsgálva megállapítható (1. ábra), hogy egyharmaduk 5 Mrd Ft alatti, további 31,9\%-uk 5 és 10 Mrd Ft közötti árbevételû.

1. ábra. A viqsgálatba bevont cégek $(n=70)$ nettó árbevétel szerinti megoszlása. (Forrás: Saját szerkesztés a HajdúBihari Napló "TOP 100” kiadványa alapján, 2018)

\begin{tabular}{|c|c|c|c|c|}
\hline \multicolumn{4}{|c|}{ Nettó árbevétel (millió forint) } & \multirow[b]{2}{*}{$33,3 \%$} \\
\hline $5000 \mathrm{Ft}$ alatt & & & 23 & \\
\hline $5000-9999 \mathrm{Ft}$ & & & 22 & $31,9 \%$ \\
\hline $10000-14999 \mathrm{Ft}$ & \multicolumn{2}{|c|}{$811,6 \%$} & & \\
\hline $15000-29999 \mathrm{Ft}$ & \multicolumn{2}{|c|}{$913 \%$} & & \\
\hline $30000-49000 \mathrm{Ft}$ & \multicolumn{2}{|l|}{$45,8 \%$} & & \\
\hline $50000-149999 \mathrm{Ft}$ & \multicolumn{2}{|l|}{$0 \%$} & & \\
\hline $150000-249000 \mathrm{Ft}$ & \multicolumn{2}{|l|}{ I $1,4 \%$} & & \\
\hline \multirow[t]{2}{*}{$250000 \mathrm{Ft}$ felett } & $4,3 \%$ & & & \\
\hline & $10 \%$ & $20 \%$ & $30 \%$ & $40 \%$ \\
\hline
\end{tabular}


2. ábra. A vizsgálatba bevont cégek fötevékenységének $(n=70)$ iparág szerinti megoszlása. (Forrás: Saját sz̨erkesztés a Hajdú-Bibari Napló “TOP 100” kiadványa alapján, 2018)

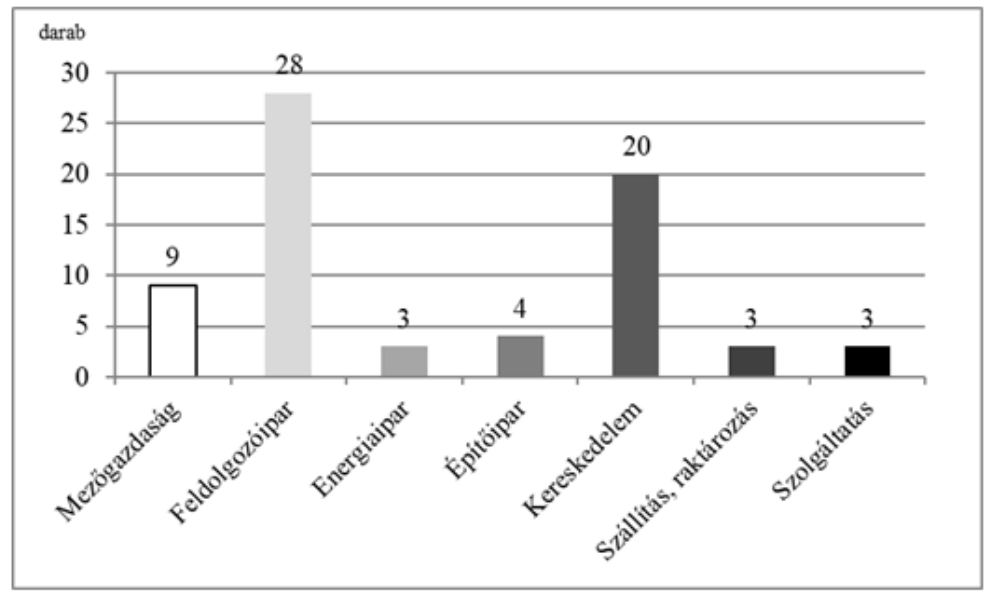

3. ábra. A vizsgálatba bevont cégek $(n=70)$ megosqlása munkavállalói létszám szuerint. (Forrás: Saját szerkesztés a Hajdú-Bihari Napló “TOP 100” kiadványa alapján, 2018)

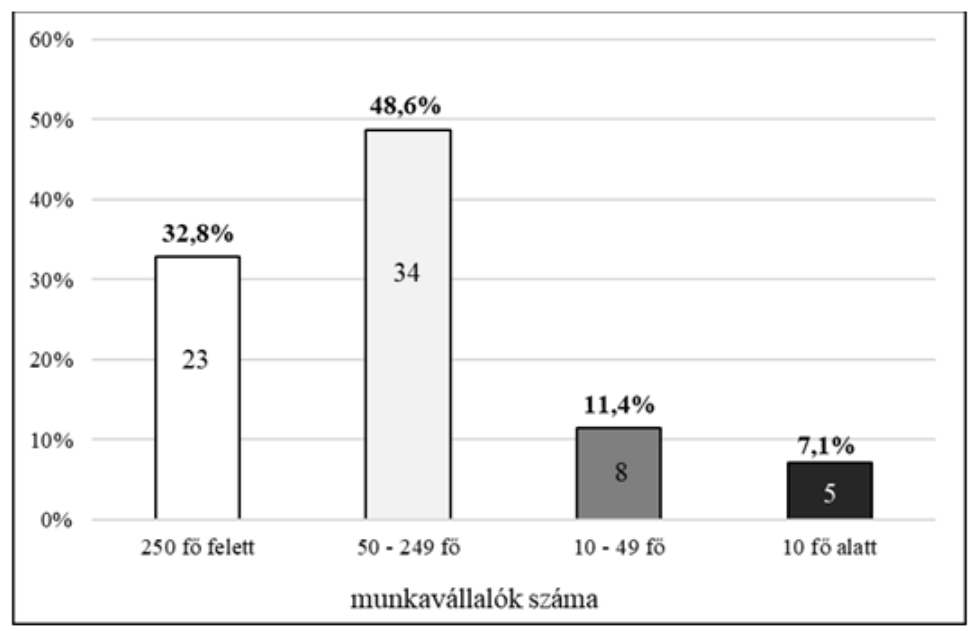

Egy cég 150 és 250 Mrd Ft közötti, három vállalat $(4,3 \%) 250 \mathrm{Mrd} \mathrm{Ft}$ feletti árbevétellel rendelkezik. A top 100 vállalkozás a megyei árbevétel $57,9 \%$-t adja, a megkérdezett 70 cég 55,2\%-ot $(1.469 .989 \mathrm{Ft})$ tudhat magáénak. A cégek tevékenységének nemzetgazdasági ágak szerinti megoszlását a 2. ábra mutatja. A legtöbb vállalkozás a feldolgozóiparban (40\%), a kereskedelemben (28,6\%), a mezőgazdaságban $(11,4 \%$, valamint a szolgáltatás területén $(7,1 \%)$ tevékenykedik. Nettó árbevétel szempontjából is a feldolgozóipar és a kereskedelem a meghatározó

A vizsgálatba bevont vállalatok 48,6\%-a 50 és 250 fő közötti munkavállalót foglalkoztat, 32,8\%nál 250 fönél több a dolgozói létszám (3. ábra).

A „top 100” nettó árbevételi rangsor első 10 cégének foglalkoztatotti létszáma 600 és 2800 fő közötti. 
A megkérdezett 70 cég a megyei munkavállalók 23,9\%-át (21.319 fő) foglalkoztatja.

\section{Eredmények}

A megkérdezett munkáltatók 38,6\%-a mondta azt, hogy a szemüveg készíttetés költségeihez hozzájárulást ad azon munkavállalók részére, akik számítógép előtt végzik munkájukat, 4,3\%-nál védőoltást kérhetnek a dolgozók, 18,7\% lehetőséget biztosít különböző orvosi vizsgálaton történő részvételre, ebből 8,6\% biztosító társasággal kötött szerződés alapján nyújtja ezt évi 1-2 alkalommal. Ugyanakkor a cégek 38,6 \% kijelentette, hogy semmiféle egészség-megőrzéshez köthető orvosi ellátásra és/vagy szûrővizsgálatra nem nyújt támogatást dolgozói számára (4. ábra).

A kutatásunk kezdetén azt gondoltuk, hogy számos magyarországi nagyvállalat biztosít valamilyen sportolási lehetőséget a munkavállalói részére, hiszen gyakran találkozhatunk olyan újsághírrel, amely arról számol be, hogy „új trendek a vállalati egészség területén idehaza is" (HR Power, 2018), „hosszú távú egészségfejlesztési programok a munkahelyeken hazánkban is" (Grantis, 2019), „életmódot formálnak a munkáltatók" (Medicalonline, 2017). A válaszok kiértékelése után szembesültünk azzal, hogy a 70 válaszadó cég közül mindösszesen $21(30 \%)$ tesz valamit azért, hogy dolgozói fizikai aktivitást végezzenek. Ebből 5 cég ezt csak az általa szervezett sportnapon teszi. $10 \%$ uk biztosít belépójegyet vagy bérletet valamely edzőterembe vagy uszodába. Az egyéb választ adók (10\%) elmondták, hogy a cafetéria keretében a munkavállalónak lehetôsége van az ilyen módon megkapott fizetésen kívüli juttatást akár edzőtermi bérlet megvásárlására is költeni (5. ábra). Az egészséges életmódhoz köthetô szaktanácsadás nyújtására vonatkozóan feltett kérdéseinkre összesen 4 nagyvállalat $(5,7 \%)$ volt az, aki azt a választ adta, hogy részben, ilyen formában is segítik dolgozóik egészségtudatosságát. Ezen cégek vezetôi elmondták, hogy a saját menzájukon biztosítanak egészséges ételeket, illetôleg heti egy napon gyümölcs/zöldség napot tartanak, valamint az egyik cég dietetikus által tartott előadásokat és főzőtanfolyamot szervezett munkavállalói egészséges életmódjának támogatása érdekében.

\section{4. ábra. A vizsgálatba bevont cégek által biẓtositott egészségügyi ellátások megoszlása. (Forrás: Saját sz̨erkesztés)}

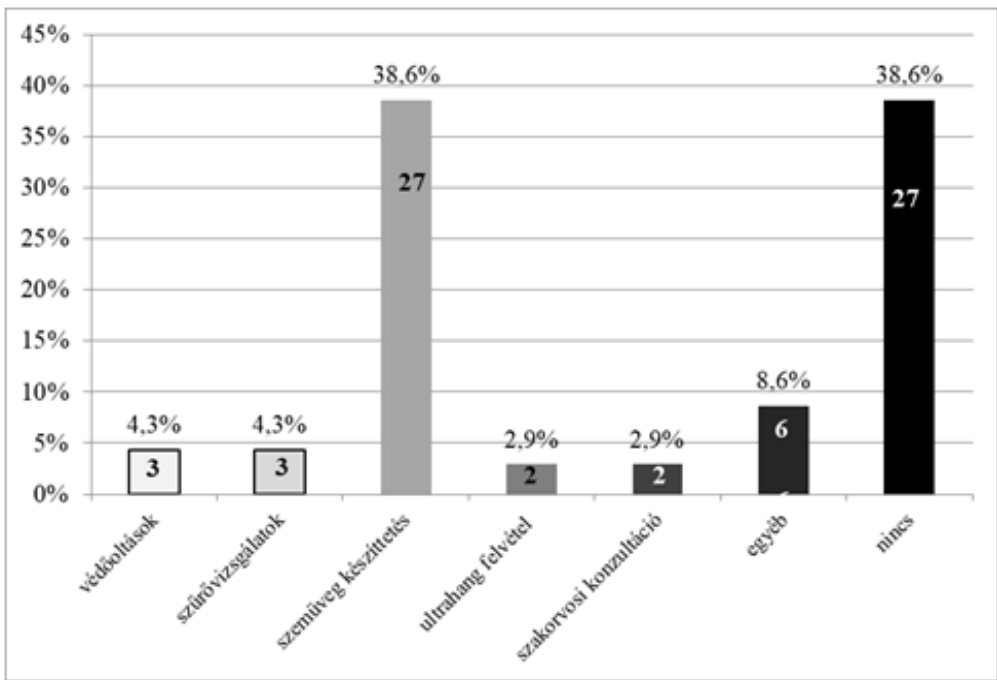




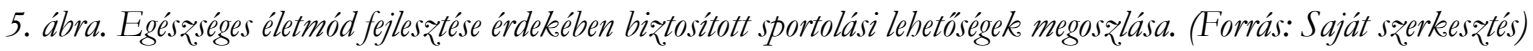

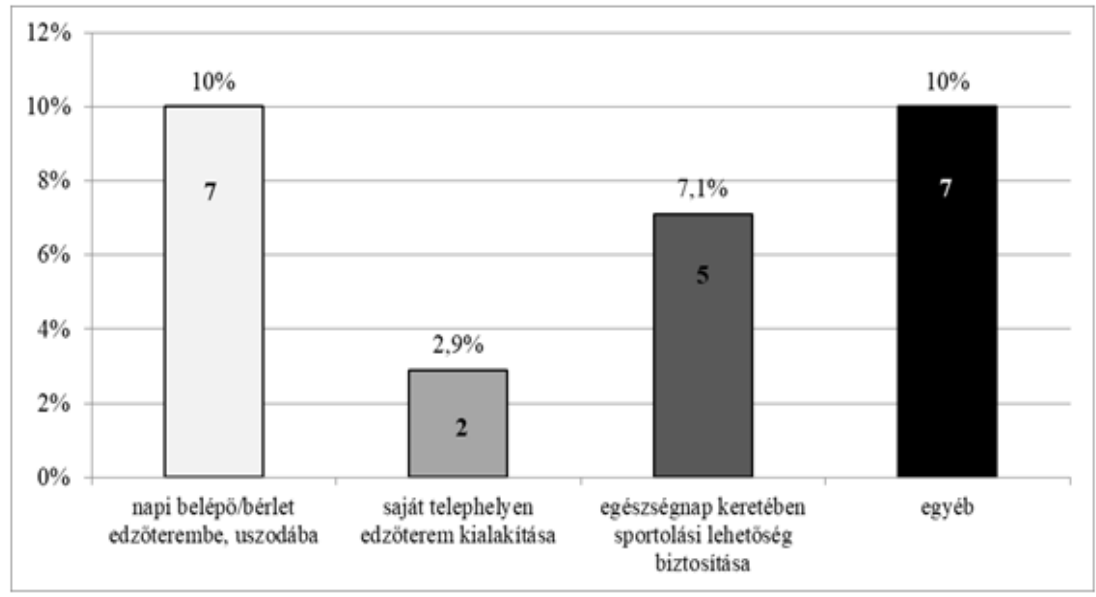

Az egyik vállalatnál az irodai dolgozók munkaidőben masszázst vehetnek igénybe. Nem volt olyan cég, aki beszámolt volna valamilyen mozgásra vonatkozó tanácsadási lehetőség biztosításáról, vagy akár stressz kezelésre irányuló, illetve dohányzásról történő leszokást segítő programot említett volna Az egyéb lehetőségek között egy esetben un. „egészséghét” évente kétszeri meghirdetését említették, melynek keretében anyajegy szűrésre, allergia vizsgálatra, laboratóriumi vizsgálatra van lehetőségük a dolgozóknak egyéni döntés alapján, és többféle csoportos sportolásra is invitálják óket az adott időszakban. Ugyanezen cég esetében egy ingyenesen hívható telefonvonal áll rendelkezésre azok számára, akik mentális segítségnyújtást szeretnének igénybe venni.

Rákérdeztünk arra is, hogy a vállalkozások vezetése részt vesz-e olyan sport- illetve egészségmegőrzéshez kapcsolódó rendezvényeken, mellyel - mint vezetôi példa - motiválni kívánják a dolgozókat. 5 esetben kaptunk pozitív választ, jellemzően helyi, az adott településen tartott futónapon illetve kerékpáros-napon történő részvétel került megnevezésre.

Megvizsgáltuk, hogy kimutatható-e valamilyen korreláció a cégek munkavállalói létszáma vagy árbevétele és az általuk biztosított egészségügyi ellátások és/vagy sportolási lehetőségek között. Mindkét esetben (egészségfejlesztés vs árbevétel illetve egészségfejlesztés vs dolgozói létszám) meghatároztuk a korrelációs együtthatót (rendre $\mathrm{r}^{2}=$ 0,$\left.2555 ; \mathbf{r}^{2}=0,1196\right)$, és vizsgáltuk, hogy az összefüggés szignifikánsnak tekinthető-e. Mind az árbevétel, mind a dolgozói létszám nagysága vonatkozásában szignifikáns (rendre $\mathrm{p}<0,01 ; \mathrm{p}<0,05$ ) kapcsolat volt kimutatható.

\section{Megbeszélés}

Kutatásunk során Hajdú-Bihar megye TOP 100 vállalkozásából 70 céget kerestünk meg. A vállalatok több, mint 2/3-ának árbevétele meghaladja az 5 Mrd Ft-ot. 81,6\% 50 főnél több munkavállalót foglalkoztat. Valamilyen, a munkavállalók számára nyújtott, egészségi állapotot javító intézkedést a munkáltatók 61,4\%-nál azonosítottunk. A megkérdezett vállalatok töredékénél található, tudatos, átfogó, rendszeres, a munkavállalók egészségét védő program.

$\mathrm{Az}$ Eurostat (2018) adatai szerint az EU-28 népességén belül a munkaképes korú (15-64 éves) személyek a népesség 64.9\%-át alkotják, míg az 
időskorúak (65 éves vagy idősebb) aránya 19,4\%. Az időskori eltartottsági ráta 29,9\%. Európa népességének elöregedése több évtizede kezdődött és hosszútávon folytatódik. Az időskorúak relatív arányának növekedését egyrészt a megnövekedett élettartam, másrészt a termékenység régóta alacsony szintje okozza, melyek miatt a korfa felülről és alulról is öregszik. Az előzetes számítások szerint a munkaképes korú népesség aránya várhatóan folyamatosan csökkenni fog 2050-ig, miközben 2080ra az EU-28 időskorú népességének aránya megközelíti a 30\%-ot.

$\mathrm{Az}$ Európa országaiban, a lakosság egészségi állapotának önbevallásos megítélése terén végzett felmérés szerint a valamilyen krónikus betegségben szenvedôk aránya átlagosan 38\%. Azoknak az aránya, akiket a mindennapos tevékenységének elvégzésében valamilyen egészségi probléma korlátoz átlagosan 28\%. Magyarországon 59-60\% az egészségüket jónak, vagy nagyon jónak tartók aránya (Statisztikai Tükör, 2018).

Magyarországon a KSH adatai szerint 2018-ban a táppénzre jogosult munkavállalók száma 4038000 fó, amelyek közül a táppénzesek aránya: 1,8\%. A táppénzes esetek száma 1 millió 202 ezer, a táppénzes napok száma 26,5 millió volt. A táppénzen lévők napi átlagos száma 73 ezer fö, a táppénzkiadás 109,5 Mrd Ft/év.

Mindezek miatt rendkívül fontos, hogy minden lehetséges módon javítsuk a munkaképes korú lakosság egészségi állapotát. Mivel a felnőtt emberek idejük jelentôs részét a munkahelyükön töltik, magától értetődőnek tűnik, hogy a munkahely egy olyan közegnek tekinthető, ahol egészségfejlesztési programokkal a népesség jelentôs hányada elérhetô.

Korábbi vizsgálatok alapján készített összefoglaló tanulmányok arra utaltak, hogy a munkahelyi beavatkozások hatásosak lehetnek a különböző rizikótényezők csökkentésében, mint például alkoholfogyasztás, dohányzás, elhízás, egészségtelen táplálkozás, fizikai inaktivitás csökkentésében
(Bordado Sköld et al., 2019; Groeneveld és munkatársai 2010; Proper és Oostrom 2019).

Ugyanakkor kutatók (Wolfenden et al., 2018) rámutattak, hogy nagyon kevés bizonyíték található a szakirodalomban arra, hogy ezen vállalati stratégiákban megfogalmazott célkitúzések gyakorlati programok formájában, következetesen és hosszú távon megvalósulnának, és hogy ezek végigvitelében a munkavállalók kitartóak lennének, életmódjukba beépülnének ezen programok elemei.

$\mathrm{Az}$ egészségügyi rendszerek finanszírozását vizsgálva többféle modellt sorol a szakirodalom. A négy leggyakrabban említett a Bismarck-féle szolidaritás elvú társadalombiztosítás, a Beveridge-féle állami egészségügyi szolgálat, az öngondoskodásra épülő rendszer (magánbiztosítás), valamint a Szemaskó-féle szocialista egészségügyi rendszer (Böröcz et al., 2019). Európa különböző országaiban az egészségügy finanszírozása nem egységes, így az állam, a vállalatok és a lakosság egészségügyre fordított kiadásai is jelentôsen különböznek és nehezen összehasonlíthatók. Emiatt az ösztönző tényezőket is másképp kell vizsgálni és keresni.

\section{Konklúzió}

Az egészség egyben gazdasági haszon is, a vállalatok egyik legfóbb értéke a képzett, lojális, egészséges munkavállaló. Az egészségtudatos munkahely ösztönzi és támogatja a dolgozók sportoláshoz, egészséges étkezéshez való hozzáférését és segíti őket minden olyan egyéb lehetőségben, ami hozzájárul az egészséges életmód megvalósításához. Ennek eredményeként kevesebb a betegszabadság, kevesebb a társadalombiztosítási kiadás, valamint eredményesebb a munkahelyen eltöltött idő. Mindenkinek: az egyénnek, a foglalkoztatónak és az államnak is érdeke (lenne), hogy a munkavállaló egészséges legyen, ugyanakkor Magyarországon jelenleg nincs igazi ösztönző rendszer, amely bármelyik felet az egészségtudatosság 
felé mozdítaná. Kimondható, hogy ezen a területen társadalmi tudatformálás szükséges, valamint az erre motiváló jogszabályi változások, mellyel párhuzamosan, ösztönzőként központi támogató források elindítása javasolt.

\section{Köszönetnyilvánitás}

A publikáció elkészítését a GINOP-2.3.2-152016-00062 és az EFOP-3.6.2-16-2017-0003 számú projekt támogatta. A projekt az Európai Unió és az Európai Regionális Fejlesztési Alap, valamint az Európai Szociális Alap társfinanszírozásával valósult meg.

\section{Irodalom}

Baicker, K., Cutler, D. \& Song, Z. (2010). Workplace wellness programs can generate savings. Health Affairs, 29, 2, 304-311. DOI: $\underline{10.1377 / \text { hlthaff.2009.0626 }}$

Bordado Sköld, M., Bayattork, M., Andersen, L. L. \& Schlünssen, V. (2019). Psycho social effects of workplace exercise - A systematic review. Scandinavian Journal of Work, Environment \& Health, pii: 3832. DOI: 10.5271 / sjweh.3832

Carolan, S., Harris, P. R. \& Cavanagh, K. (2017). Improving Employee Well-Being and Effectiveness: Systematic Review and Meta-Analysis of Web-Based Psychological Interventions Delivered in the Workplace. Journal of Medical Internet Research, 19, 7, e271. DOI: 10,2196 / imir $\underline{75583}$

Chu, H. Y., Koh, D., Moy, F. M. \& MüllerRiemenschneider, F. (2014). Do workplace physical activity interventions improve mental health outcomes?. Occupational Medicine, 64, 235245. DOI: $10.1093 / \mathrm{occmed} / \mathrm{kqu} 045$

Conn, V. S., Hafdahl, A. R., Cooper, P. S., Brown, L. M. \& Lusk, S. L. (2009). Meta-Analysis of Workplace Physical Activity Interventions.
American Journal of Preventive Medicine, 37, 4, 330339. DOI: $10.1016 /$ j.amepre.2009.06.008

Dishman, R.K., Oldenburg, B., O'Neal, H. \& Shephard, R. J. (1998). Work site physical activity interventions. American Journal of Preventive Medicine, 15, 4, 344-361. DOI: 10.1016 / s07493797 (98) 00077-4

Engbers, L. H., van Poppel, M. N., Chin, A., Paw, M. J. \& van Mechelen, W. (2005). Worksite healthpromotion programs with environmental changes: a systematic review. American Journal of Preventive Medicine, 1, 61-70. DOI: 10.1016/i.amepre.2005.03.001

Groeneveld, I. F., Proper, K. I., van der Beek, A. J., Hildebrandt, V. H. \& van Mechelen, W. (2010). Lifestyle-focused interventions at the workplace to reduce the risk of cardiovascular disease - a systematic review. Scandinavian Journal of Work, Environment \& Health, 36, 3, 202-215. DOI: $10.5271 /$ sjweh. 2891

Hajdú-Bihari Napló (2018). "Top 100". Inform Média Lapkiadó Kft., Debrecen.

Joyce, S., Modini, M., Christensen, H., Mykletun, A., Bryant, R., Mitchell, P. B. \& Harvey, S. B. (2016). Workplace interventions for common mental disorders: a systematic meta-review. Psychological Medicine,46, 683-697. DOI: $\underline{10.1017 / \mathrm{S} 0033291715002408}$

Katz, D. L., O'Connell, M., Yeh, M. C., Nawaz, H., Njike, V., Anderson, L. M., Cory, S. \& Dietz, W. (2005). Public health strategies for preventing and controlling overweight and obesity in school and worksite settings: a report on recommendations of the Task Forceon Community Preventive Services. Morbidity and Mortality Weekly Report Recommendations and Reports, 54, 112.

Kleinman, N., Abouzaid, S., Andersen, L., Wang Z. \& Powers, A. (2014). Cohort Analysis Assessing Medical and Nonmedical Cost Associated With Obesity in the Workplace. American College of $\mathrm{Oc}$ - 
cupational and Environmental Medicine, 56, 2, 161 170. DOI: 10.1097 / JOM.0000000000000099

Knoche, K., Sochert, R., Houston, K. \& Felszeghi, S. (2012). Egészséges munkabelyek krónikus beteg munkavállalók számára Útmutató. European Network for Workplace Health Promotion, Országos Egészségfejlesztési Intézet.

Koopmans, L., Bernaards, C. M., Hildebrandt, V. H., Schaufeli, W. B., de Vet Henrica, C. W. \& van der Beek, A, J. (2011). Conceptual frameworks of individual work performance: a systematic review. Journal of Occupational and Environmental Medicine, 53, 8, 856-866. DOI: 10.1097 $\angle$ JOM.0b013e318226a763

Martin, A., Sanderson, K. \& Cocker, F. (2009). Meta-analysis of the effects of health promotion intervention in the workplace on depression and anxiety symptoms. Scandinavian Journal of Work, Environment \& Health,35, 1, 7-18. DOI: $\underline{10.5271 / \text { sjweh. } 1295}$

McDaid, D., Curran, C. \& Knapp, M. (2005). Promoting mental well-being in the workplace: a European policy perspective. International Review of Psychiatry, 17, 5, 365-373. DOI: $\underline{10.1080 / 09540260500238397}$

Mehta, S., Dimsdale, J., Nagle, B., Holub, C. K., Woods, C., Barquera, S. \& Elder, J. P. (2013). Worksite Interventions Improving Lifestyle Habits Among Latin American Adults. American Journal of PreventiveMedicine, 44, 5, 538-542. DOI: 10.1016/i.amepre.2013.01.015

Navratil-Strawn, J., Hartley, S. \& Ozminkowski, R. J. (2016). Frequency of Participation in an Employee Fitness Program and Health Care Expenditures. Population Health Management, 19, 5, 315-323. DOI: 10.1089/pop.2015.0102

Peluso, M. A. \& Guerra de Andrade, L. H. (2005). Physical activity and mental health: the association between exercise and mood. The Clinics, 60, 1, 61-70. DOI: $\underline{10.1590 / s 1807-}$ $\underline{59322005000100012}$
Proper, K. I. \& van Oostrom, S. H. (2019). The effectiveness of workplace health promotion interventions on physical and mental health outcomes - a systematic review of reviews. Scandinavian Journal of Work, Environment \& Health, pii: 3833. DOI: $10.5271 /$ sjweh. 3833

Sanderson, K. \& Andrews, G. (2006). Common mental disorders in the workforce: recent findings from descriptive and social epidemiology. The Canadian Journal of Psychiatry, 51, 2, 63-75. DOI: $10.1177 / 070674370605100202$

Schulte, P.A., Wagner, G. R., Ostry, A., Blanciforti, L. A., Cutlip, R. G., Krajnak, K. M., Luster, M., Munson, A. E., O'Callaghan, J. P., Parks, C. G., Simeonova, P. P. \& Miller, D. B. (2007). Work, Obesity, and Occupational Safety and Health. American Journal of Public Health, 97, 3, 428-436. DOI: $\underline{10.2105 / \mathrm{AJPH} .2006 .086900}$

Schultz, A. B., Chen, C. Y. \& Edington, D. W. (2009). The Cost and Impact of Health Conditions on Presenteeism to Employers A Review of the Literature. Pharmacoeconomics, 27, 5, 365378. DOI: 10.2165/00019053-200927050$\underline{00002}$

Sjøgaard, G., Christensen, J. R., Justesen, J. B., Murray, M., Dalager, T., Fredslund, G. H. \& Søgaard, K. (2016). Exercise is more than medicine: The working age population's well-being and productivity. Journal of Sport and Health Science, $\quad 5, \quad 2, \quad 159-165 . \quad$ DOI: 10.1016/i.jshs.2016.04.004

Thompson, D., Edelsberg, J., Kinsey, K. L. \& Oster, G. (1998). Estimated economic costs of obesity to U.S. business. American Journal of Health Promotion, 13, 2, 120-127. DOI: 10.4278/0890-1171-13.2.120

Waxman, A. (2004). WHO Global Strategy on Diet, Physical Activity and Health. Food and Nutrition Bulletin, 25, 3, 292-302. DOI: $\underline{10.1177 / 156482650402500310}$ 
Wolf, A. M. \& Colditz, G. A. (1998). Current estimates of the economic cost of obesity in the United States. Obesity Research \& Clinical Practice. 6, 2, 97-106.

Wolfenden, L., Goldman, S., Stacey, F. G., Grady, A., Kingsland, M., Williams, C. M., Wiggers, J., Milat, A., Rissel, C., Bauman, A., Farrell, M. M., Légaré, F., Charif, B. A., Zomahoun, H. T. V., Hodder, R. K., Jones, J., Booth, D., Parmenter, B., Regan, T. \& Yoong, S. L. (2018). Strategies to improve the implementation of workplace based policies or practices targeting tobacco, alcohol, diet, physical activity and obesity. Cocbrane Database of Systematic reviews, 11, CD012439.

Young, S. N. (2007). How to increase serotonin in the human brain without drugs. Journal of Psychiatry \& Neuroscience, 32, 6, 394-399.

Jogszabályok:

2012. évi I. törvény a munkatörvénykönyvéről

Internetes hivatkozások:

Böröcz, I., Kisapáti, A. \& Nagy, L. (2019). Elemzés az egészségügy finanszírozásáról. Állami Számvevőszék.(Web:https://asz.hu/storage/fil es/files/elemzesek/2019/egeszsegugy finanszir ozasa20190628.pdf) (Letöltés: 2019. 03. 04.)

EUROSTAT (2018). Népességszerkezet és a népesség elöregedése.

(Web: https://ec.europa.eu/eurostat/statisticsexplained $/$ index.php?title $=\quad$ Population_structure and ageing/hu) (Letöltés: 2019. 03. 04.)

FACTS 94 Európai Munkahelyi Biztonsági és Egészségvédelmi Ügynökség. (2010). Munkahelyi egészségfejlesztés munkavállalók számára. (Web: https://osha.europa.eu/hu/tools-andpublications/publications/factsheets/94) (Letöltés: 2019. 03. 04.)

Grantis (2019). Ezért érdeke a munkáltatóknak is az egészséges munkavállaló.
(Web:https://grantis.hu/ezert-erdeke-amunkaltatoknak-is-az-egeszseges-munkavallalo/ (Letöltés: 2019. 03. 04.)

HERO (Health Enhancement Research Organization) Health, Productivity, and Performance Study Committee (2015). Exploring the Value Proposition for Workforce Health. (Web:https://hero-health.org/wpcontent/uploads/2015/02/HPP-BusinessLeader-Survey-Full-Report FINAL.pdf ) (Letöltés: 2019. 03. 04.)

HR Power (2018). Ezek a legújabb irányzatok a vállalati egészség területén. (Web:http://hrpwr.hu/fejlodes/cikk/ezek a le gujabb iranyzatok a vallalati egeszseg_teruleten\#) (Letöltés: 2019. 03. 04.)

KSH (2019). Az egészségbiztosítási ellátásban részesülők táppénzes adatai. Központi Statisztikai Hivatal (Web: https://www.ksh.hu/docs/hun Lxstadat/xstadat evkozi/e fsp002.html) (Letöltés: 2019. 03. 04.)

KSH (2019). Fókuszban a megyék - 2019. I. negyedév, Hajdú-Bihar megye. (Web: http://www.ksh.hu/docs/hun/xftp/megy/191 Lindex.html) (Letöltés: 2019. 03. 04.)

Medicalonline (2017). Életmódot formálnak a munkáltatók. (Web:http://medicalonline.hu Leu gazdasag/cikk/eletmodot formalnak_a m unkaltatok) (Letöltés: 2019. 03. 04.)

Statisztikai Tükör (2018). Egészségi állapot és egészségmagatartás, 2016-2017. Központi Statisztikai Hivatal (Web:http://www.ksh.hu /docs/hun/xftp/stattukor/egeszsegallapot1617 .pdf) (Letöltés: 2019. 03. 04.)

Willis Health and Productivity (2014). Survey report. (Web:https://www.willis.com/ documents/publications/Services/Employee Benefi ts/FOCUS 2014/20140402 50074_HCP Heal th Prod FINAL V2.pdf ) (Letöltés: 2019. 03. 04.) 